\title{
The religious dimension of cinematographical consciousness in postmodern culture
}

\author{
von Sylvain De Bleeckere
}

As an introduction to the subject to be discussed, I wish to draw attention to Rudolf Arnheim's book Film as Art. Arnheim was one of the first European intellectuals to write an apologia for the new medium of film. In his theory, published in the thirties, he emphasized that film is a new art which merits its own and dignified place among the arts. He called film the tenth Muse. When reviewing his book in the fifties, the author explained that he had tried to lay down the aesthetic code of the new art. He hoped to preserve that code as "a book of standards" for the coming generations of filmmakers. In the review, he also presented his "book of standards" as a useful instrument in the hands of young directors for making clearer films. ${ }^{1}$ The theoretical will to standardize and to diagnose impurities is typical for the cultural project of the "enlightened“ man. It is the project of modernism, the genealogy of which dates back to the modern times, especially to the Age of Reason. Arnheim's theory is grafted onto modernism. The author himself is not aware that his theory is indebted to the philosophical aprioris of modernism. The fundamental reason for that is the absence of any explicit concept of culture. He develops his theory without investigating its cultural context. Furthermore, he completely overlooks the indispensable cultural dimension of film.

In my cultural-philosophical essay on the religious dimensions of film, I regard ,culture' as the anthropological phenomenon in which religious and cinematic expressions can be interwoven. Culture represents the world of human work and life, which not only develops in the history of mankind, but also in that of the planet earth and even in that

Prof. Dr. Sylvain de Bleeckere lehrt Philosophie am P. H. A. I. (Campus Diepenbeek, Belgien) und am Center for Ecclesiastical Studies in Louvain (Belgien).

1 R. Arnheim, Film as Art; London (1958) 1983, 15-16. The author presents his book as "a book of standards" and, when discussing the films of a new generation of filmmakers, he notes: "These films and those of other talented artists, however, are also beset by the impurities that are so amply diagnosed in this book. It is the business of the theorist to inspect the tools and to ask that they be cleaner."

2 As the physicist and mathematician Stephen W. Hawking in his book A Brief History of Time: From the Big Bang to Black Holes (New York: Bantam Books 1988), we can speak about "the history of time“. Cf. also the film A Brief History of Time (USA, 1992, Errol Morris), based on Hawking's book with the same name. 
of time itself. ${ }^{2}$ The fact is that film has become an important part of a changing culture. Since its appearance at the end of the 19th century, film has even grown into a first-rate cultural scene. It is situated in the middle of culture. Now, one can question how this new center of culture is related to religion, that former center of the cultural scene. There is a great intellectual temptation to address that question without taking cultural and historical considerations into account. Culture, religion and film are indeed related to each other in, and not beyond, history. Within the scope of this essay, I confine myself to discuss only one aspect of the basic question. The aspect I envisage is that of the postmodern cultural project which developed during the second half of the 20th century. Increasingly, it took place alongside and even against modernism. I consider at length some important elements of the postmodern culture. These elements indicate a cinematographical, as well as a religious consciousness in postmodern culture. But for a methodical approach, a preparatory description of the structural relation between the culture of modernism, film and religion is required. Such a description implies an understanding of the reason why the modern phenomenon of film could be mastered by modernism in the first decades of its appearance.

\section{The Modern Medium of Film}

By concentrating from the very beginning of his book on the relation between film and the arts, Arnheim forgot the primordial fact that film is in the first place connected with the modern world of scientific research, technological machine construction and industrial capital. At the end of the 19th century, film grows like a ripe fruit attached to the large tree of modern industrial society. A clear sign of that is the first film studio, called the "Black Maria" ${ }^{3}$ Film made its arrival through the gateway of industry. That gateway was opened definitively and irreversibly by the modernism of the Age of Enlightenment. Consequently, film was not experienced in its early days as a new exponent of the artistic genius of mankind. Rather, it was initially understood as one of the manifold and growing expressions of the modern genius that was continuously expanding its scientific, technological and economic power over space and time. Even more than with photography, film allowed "the man of the new age" to enlarge his "Faustic" powers over time. He had now invented a magic instrument to record time itself. So, not surprisingly, the motion-picture camera was promptly claimed as its own by modernism. It forced film to take over a leading part in its greatest experiment on the cultural scene of the 20th century.

3 D.A. Cook, A History of Narrative Film (New York: W.W. Norton \& Company, 1990), 8. The first motion-picture studio had been constructed by Dickson in 1893 and it was called the "Black Mary" because it was covered with protective tar-paper strips. 
With the breakthrough of the Communist October Revolution in 1917, the modern film medium was charged with playing an important part in the realization of modernistic objectives in the Soviet Union. Under the supervision of the Communist party, Sergei Eisenstein formulated its first theory. The key of the theory is the concept of montage, better known, in the English-speaking world, as "editing".4 Eisenstein borrowed the word montage directly from the industrial machine culture, the extension of which was a priority in the revolutionary policy of the Soviet Party. That means, to begin with, that film was not considered as an artistic medium, even when it made use of the different arts. Film appeared as a cultural technological machine, the aim of which was to clear the mind of the oppressed people of all kinds of alienation and to lead it to the pure high point of dialectical insights. Seen in this way, film must be the adequate medium for the expression of the liberated and emancipated collective mind of the proletariat and so even of mankind itself. In that communistic cultural project, modernism reached its historical climax. The utopian aim of the Enlightenment to free mankind once and for all from the ,Unmündigkeit' was now within arm's reach. Finally it had become possible to realize this aim in a technical and strategic, i.e. efficient, way.

The immediate consequence of such a vision and practice was that films had to be dictated by a pure and enlightened Reason. We can see the concrete implications of that very clearly in the work of Eisenstein. It shows how film was a propaganda machine for the Great Truth, "the Pravda". Eisenstein names the true film, the Soviet film, "the intellectual film-art". ${ }^{5}$ He considered "the living man" as the greatest enemy of that true film-art. He envisages the concrete Russian man, attached to old folk customs. That attachment to tradition makes him intellectually underdeveloped and completely disqualified to understand the scientific truth about himself and his historical situation. That is the reason why the Russian people need a thorough shake-up. This

4 S. Eisenstein, Montage. Het konstruktie-principe in de kunst (Montage. The principle of construction in art).(Nijmegen: SUN, 1981), 30: „Film art is first of all montage." (Authors translation from the Dutch edition of Eisenstein's article Outside the Film Picture (Moskow, 1929).

5 Eisenstein developed his idea of "the intellectual film", and of "the living man" as the enemy of that film, in his study Perspectives, originally published in the periodical Iskoesstwo 1-2 (1929). Cf. also D.A.Cook's A History of Narrative Cinema, 184: „Intellectual or ideological montage‘ was the type that most fascinated Eisenstein in both theory and practice...Eisenstein also conceived that montage was capable of expressing abstract ideas and making direct intellectual statements. " Eisenstein himself considered his third film October (1928) as such an intellectual montage film and especially the "gods" sequence of the film as a more complex example of this montage. With this sequence, Eisenstein wants to "enlighten“ the spectator by an atheistic film argument. 
masive programme is to be accomplished by the Sovjet filmmakers. Like the liberated man portrayed in Plato's well-known Cave Myth, they must lead the Russian people out from the shadows to true intellectual and eternal light.

Seen from a stylistic point of view, the filmmaker uses the technique of the industrial assembly (montage) to forge film into the politically chosen instrument of cultural and educational policy. Film becomes an assembled image-machine, which can only be called a work of art because of its ingenious construction, just like the structural works of the civil engineer. Like an industrial machine, film is composed of removable parts which are assembled together following a fully rational procedure. In accordance with the strict regulation of modernism, only enlightened reason can produce real art. Eisenstein considers the intellectual film to be the last link in the chain of means necessary to accomplish the cultural revolution. This sort of film brings to completion the final dialectical synthesis in the form of a monistic and all-embracing system encompassing the fields of collective education and teaching, as well as all the arts. Thanks to the intellectual film, the historical development of the arts attains its everlasting happy end. It is not only modern film that ceases, from that historical moment on, to be an art in the traditional sense; the intellectual film puts all the arts at the service of the absolute Idea, which found its first historical figure in the Soviet society of "the Pravda".

The historical example of Eisenstein's work is of great importance for the comprehension of the relationship between modernism, film and religion. Modernism manifests itself here in its most clear cultural form, namely, in that of self-assured atheism. It proclaims religion to be an historical phase of Unmündigkeit, definitely overruled by the Enlightenment. In this sense it is highly significant that the Communist revolution of 1917 recognized the painting The Black Square (1914-1915), of the Russian painter Kazimir Malevich, as the icon of the new age. ${ }^{6}$ This is the period of the atheist who, with a single brushstroke, effaces all religious icons. Following the famous example of Malevich, Eisenstein promotes film to the art of the new and atheistic man. Under the influence of the Communist revolution Eisenstein broke off completely with his religious education, and became an confirmed believer in Marxism. As the master of the Soviet film, he stood at the cradle of the

6 W.A.L. Beeren, J.M. Joosten, (ed.), Kazimir Malevich (1878-1935) (Moscow: Ministry of Culture USSR/Amsterdam: Stedelijk Museum, 1988), 14. In his introduction to the important Leningrad-Moscow-Amsterdam exhibition (11.1988-05.1989), W. Beeren declares: "The Black Square is the first and the most radical expression of Suprematism, created by Malevich. .. The painting Black Square meets perfectly Malevich's opinion that a painted shape is not a derivation of reality, but leads an independent, unique life, and has its own expressiviness." 
machine image of the Communist revolution. The Soviet film in general institutionalized the heroic image of the industrial machine through many sequences exhibiting working factory machines and large farming machines. The little film camera was the humble, but powerful, servant of that machinery, as is evidenced by Dziga Vertov's Kinopravda, and his film The Man with a Movie Camera. ${ }^{7}$ In the film-image of modernism the industrial machine takes over the church's cultural position. The static form of the church's architecture is stylistically linked to the static dimension of religious icons, while the movie camera is aesthetically associated with the moving industrial machine. From the point of view of modernism, the camera, seen as the machine of the moving image, naturally belongs to the industrial world of mechanized progress.

The Soviet film certainly has the value of an historical paradigma for the study of the cultural relation between film and religion. It shows that any form of modernism aims at using the new film medium in order to bring about the liberation of mankind. In that case, film always serves as an ideological instrument for the enlightened Idea of Progress. Such an idea always labels religion as a cultural stage that must be surpassed in order to make planned progress possible. Through his films, the enlightened filmmaker can unmask religion for a broad public and propagate the enlightened lifestyle. With the collapse of the Soviet Union at the end of the 20th century, modernism has lost, to be sure, its most extreme historic form. But elsewhere too, it begins to loose its ideological grip on culture in general and on film in particular. Since the eighties, a postmodern cultural consciousness has been growing. It creates a new place for a completely different cinematographical consciousness. It has the will to contemplate the cultural relationship between film and religion in a constructive way. A new light shines on film and religion in postmodern culture. Both can now be seen, in many regards, as cultural correlates instead of being understood as antipodes. I want to describe in detail the meaning of that postmodern correlation between film and religion in two different moves. In the first step, I explain in what sense the notion of postmodern culture shall be used; in the second, some fundamental aspects of the indicated correlation will be discussed.

7 L. et J. Schnitzer, Histoire du cinéma soviétque 1919-1940 (The History of the Sovjet film) (Paris: Pygmalion/Gérard Watelet, 1979), 45: "Kinopravda, Ciné-Pravda, Ciné-Vérité. Jouant sur le nom de son journal "filmé, Dziga Vertov parlait d'une ,ciné-veritét plus belle, plus riche, plus vraie que la vérité du réel“. Dziga Vertov (b. Denis Kaufman, 1986-1954) and "his small band of committed young documentarists call themselves the Kinoko (from kino-oki - ,cinema-eyes') ... His most exhaustive essay in the "kino-eye' technique was his major work, The man with a Movie Camera (Chelovek s kinoapparatom, 1929)“ (D.A.Cook, A History of Narrative Cinema, 142-144). 


\section{Three postmodern cultural traces}

In itself, the notion of a postmodern culture is not unambiguous. A philosophical debate concerning the possible sense or nonsense of the notion of postmodernism falls outside the scope of my essay. ${ }^{8}$ For this reason, I prefer to use here the notion of postmodern culture rather than speaking about postmodernism. That makes it possible to modify the importance of the notion of postmodern culture during the process of thinking itself. This process follows three cultural traces of meaning, namely the epistemological, the decentric and the aesthetic one. In my view, these traces express a minimal agreement on the content of postmodern consciousness in contemporary Western culture.

The epistemological trace indicates the thoroughgoing relativization of the Pravda-concept. It concerns a general rejection of any ideological figure of Truth, written with a capital letter. The popular postmodern formula says that there are no longer any "great stories". 9 The most recent one was that of a secular and atheistic modernism. The postmodern period shows great sensitivity to a multiformity in vision and behaviour, i. e. cultural expression. It is interesting to note that, via the very different philosophies of Martin Heidegger and Ludwig Wittgenstein, the epistemological trace brings postmodern culture to an important reevaluation of language. Postmodern philosophy concentrates on the emancipation of language from any kind of ideological restriction. ${ }^{10}$ This philosophical emancipation occurs in the postwar period precisely when everybody concludes that language has forfeited its cultural dominance and faces a deep crisis. In this context, Neil Postman leads many Western intellectuals in condemning the dominant image culture. He leads this culture back to television, and makes of the moving image the scapegoat of the decay in Western culture.11

8 In continental European philosophy the postmodernism debate is dominated by the discussion between Jean-François Lyotard and Jürgen Habermas.

9 In his study La condition postmoderne. Rapport sur le savoir (Paris: Ed. de Minuit, 1979), Lyotard launched the philosophical formula of postmodernism, by arguing that "métarécits“ are no longer possible.

10 M. Heidegger, Unterwegs zur Sprache (Pfullingen: Günther Neske, 1959, 1971), 254-255. In opposition to the modernistic point vision on language of Wilhelm von Humboldt (1767-1835), Heidegger articulates his own postmodern vision in his famous diction ,Die Sprache spricht' (The language speaks). In his own way Wittgenstein writes already in 1945 his postmodern vision on language, seen as a complex of different Sprachspiele (language games), down in his Philosophische Untersuchungen (Frankfurt/M.: Suhrkamp, 1971), 70: „Unsere klaren und einfachen Sprachspiele sind nicht Vorstudien zu einer künftigen Reglementierung des Sprache. ... Wir wollen in unserem Wissen vom Gebrauch der Sprache eine Ordnung herstellen: eine Ordnung zu einem bestimmten Zweck; eine von vielen möglichen Ordnungen; nicht die Ordnung."

11 N. Postman, Amusing ourselves to death (New York: Viking/Penguin Inc., 1985). 
Nonetheless, Postman's thesis stands in contrast with the analyses of the literary theoretician George Steiner. He demonstrates that the main cause of the growing cultural impotence of language is rather be found in the inescapable historical dimension of language itself. Each language is a living cultural system with its typical history of growth and decline. Inspired by the philosophy of Martin Heidegger, Steiner thinks that the contemporary empoverishment of language is the side-effect of the increasing technical way of thinking. ${ }^{12}$

Up to the present, however, the epistemologic trace of postmodern philosophy has drawn attention to the medium of language without displaying any sensitivity for the new medium of the image and its own cultural value. Particularly by way of the film-image, the modern technical world creates a completely new medium for a mankind that lives and thinks in a world full of all kinds of machines. Such a positive understanding of the image culture is mainly developed outside the traditional academic world, which has occupied itself either with elaborating the technological language of the scientific disciplines, or with defending almost desperately the classical literary function of the spoken and written mother language. By contrast, sound and image engineers under the direction of filmmakers in American and especially in European studios have explored the new intellectual field of the cinematographic image. These men have discovered the ways of thinking opposite to the new image. Looking back on the first century of film history, it is clear that the will to explore the new image has always been stronger than the will to confine it within the epistemological limits of modernism.

By following the contemporary epistemological trace of postmodern culture, a growing number of educated people are finding their way into the intellectual kingdom of the cinematographical image. When human thinking becomes increasingly aware of the fact that it has being dominated by different figures of the concept of truth, then an post-ideological area of thinking appears. This epistemological trace shows the way beyond the impotence of language to the still young and powerful intellectual force of film. ${ }^{13}$

12 G. Steiner, Language and Silence. Essays 1958-1966 (London: Faber and Faber, 1967/1985), 43,46: "Until the seventeenth century, the sphere of language encompassed nearly the whole of experience and reality; today, it comprises a narrower domain. ... Larger areas of meaning and praxis now belong to such non-verbal languages as mathematics, symbolic logic, and formulas of chemical or electronic relation. ... The world of words has shrunk." "The instrument available to the modern writer is threatened by restriction from without and decay from within."

13 Film can be understood as a visual medium in which new ways of thinking can be found. Cf. I. Jarvie, Philosophy of the film. Epistemology, ontology, aesthetics (London/New York: Routledge \& Kegan Paul, 1987), and G. Deleuze, "La pensée et le cinéma", in Cinéma 2. L'image-temps, (Paris: Les Ed. de Minuit, 1985, 203-245). 
I call the second trace of postmodern culture, as already mentioned, the decentric trace. Whereas modernism appears to be the last exponent of a centric culture, postmodern culture seems to be decentric. In modernism, the autonomous and pure Reason of Mankind is always, in one way of another, the center. Postmodern consciousness looks upon such an anthropocentric middle as culturally extinct. ${ }^{14}$ Earlier, modernism had denounced any kind of supernatural center, mostly identified with God, placing, instead, enlightened man in the focal point of history; now postmodern thinking has unmasked that modernistic center as a final illusion of a too self-assured mankind. By doing so, the decentric trace of postmodern culture points to both religion and film. Religion is no longer considered as an expression of a not-yet emancipated, still infantile mankind. But in a postmodern society the traditional churches and their theologies no longer constitute the big centers from which the religious life of mankind is managed and dominated.

The postmodern development of film in the 20th century is a sign of the two mentioned phenomena. Film can be seen as a privileged and decentered field for postmodern mankind, in which it can freely express its religious feelings and thoughts. Film creates an important extraecclesiastical and non-clerical, as well as non-modernist, space of religious evocation for the person who learns to live without "human, all too human" illusions. ${ }^{15}$ This also implies that in postmodern culture the fixed and traditional boundaries between cultural expressions cease to be excluding limits and metamorphose into meeting points. Also the stylistic boundaries between arts and genres, mostly laid down by the aesthetics of modernism, are fading away and even disappearing. In this aspect, film is the pre-eminently postmodem medium. ${ }^{16}$ By following the decentric trace of postmodern culture, it also becomes clear that the possible religious dimension of film decenters the traditional thinking of theology. The religious implications of film in postmodern culture go further than evaluating film as just a new hierophantic medium for the

14 M. Foucault, Les Mots et les Choses (Paris: Ed. Gallimard, 1966), 398: "L'homme est une invention dont l'archéologie de notre pensée montre aisément la date récente. Et peut-être la fin prochaine." Foucault was inspired by the famous words of Friedrich Nietzsche's Zarathustra about "the death of God".

15 The term "human, all too human" is borrowed from Nietzsche's book Menschliches, Allzumenschliches (1878). The German philosopher Friedrich Nietzsche (1844-1900) is considered to be the first real postmodem thinker.

16 In contrast to the point of view of Arnheim (Film as Art, 188), who can not find a structural relation between the opera and the film, many filmdirectors have found in Wagner's concept of Gesamtkunstwerk a true source of inspiration. Here, I refer only to the films of Luchino Visconti, Hans Jürgen Syberberg, Francis Ford Coppola and, recently, Peter Greenaway. 
theological truth. ${ }^{17}$ In the treatment of film and religion, ecclesiastical theology can no longer act as the third term, i. e. as the center which atunes the two other terms to each other. Along the decentric trace in which the cinematographical and religious expression displays its strength, no hierarchical approach of the relation between film and religion can be applied any longer. This cultural situation obliges ecclesiastical theology to take seriously in a decentric manner the request of the Second Vatican Council to reflect upon "the signs of the time“.

The third postmodern trace in contemporary culture is aesthetic in character. The understanding of its own nature stems from the assessment that postmodern conciousness has manifested itself for the first time in an explicit way within the world of art. That has taken place especially in the world of architecture. ${ }^{18}$ Indeed, postmodern culture is in a broad sense backed up by the will to liberate art from all kinds of ideological patronizing. Thus, architecture has found its postmodern style ridding itself of the fixed frame of modernistic architecture. Mark C. Taylor was the first theologian to present a pronounced postmodern theological interpretation of the situation in which architecture and other arts are expanding. ${ }^{19}$ In his so-called postmodern a/theological interpretation of culture, the keyword is "disfiguring". It signifies the postmodern refusal to aesthetically represent or mime any sort of metaphysical Essence. The postmodern artist does not want to copy any pre-existing Model. ${ }^{20}$ Plastic figuration

17 An exemplary of the hierophany approach of film, can be found by Michael Bird, "Film as Hierophany“, in: J.R. May, M. Bird (ed.), Religion in Film (Knoxville: The University of Tennessee Press, 1984, 3-22). Such an approach belongs to the theoretical tradition that begins with Paul Schrader's Transcendantal Style in Film: Ozu, Bresson, Dreyer (New York: Da Capo, 1988, reprint. Originally published: Berkeley: University of California, 1972), 9: "The critical approach I associate with the term ,transcendantal style'...may be loosely called an Eliade-Wolfflin method. This method is...a study of contemporary artistic hierophanies through the analysis of common film forms and techniques." Schrader's conclusions dealing with the religious film (162-169), owes a debt to the point of view of Amédée Ayfre, the French pionier of the hierophany approach, as can be found in his Dieu au cinéma. Problèmes esthétiques du film religieux (Paris: Presses Universitaires de France, 1953).

18 Ch. Jencks, What is Post-Modernism? (New York/London: St. Martin's Press/Academy Ed., 1986). Ch. Jencks, Die Postmoderne. Der neue Klassizismus in Kunst und Architektur (Stuttgart: Klett-Cotta, 1987).

19 Mark C. Taylor, Erring. A Postmodern A/theology (Chicago: The University of Chicago Press, 1984). Mark C. Taylor, Disfiguring: Art, Architecture, Religion (Chicago: The University of Chicago Press, 1992).

20 Ibid.,6 : "The two parts of disfigure suggest the negation or deprivation of form, image, likeness, or representation; the removal of symbol, ornament, design, or pattern." 
refuses to be a copy of one or the other existing model. The image receives its form from the refusal to re-present anything. For Taylor, this disfiguring rejects the traditional "theo-esthetics", which is modeled by the will to imitate and realize the Eternal, the Divine, the Absolute, in the fleeting order of space and time. That utopian dream is even recognizable in atheistic modernism. Taylor's a/theology finds in postmodern architecture and art the paradigm of the postmodern endorsement of disfiguration.

But a basic question is why film remains a blind spot in the vision of the a/theological, postmodern discourse. Does film still possess an inferior place in the rank of arts, in the eyes of the intellectual? The $\mathrm{a} /$ theological blindness for film is rather due to the unarticulated opinion that by nature film has an essence too modernistic. Is the visuality of the film-image too strong to disfigure the illusion of representation? This question returns us, by way of the aesthetic meaning-trace, to the discussion on the aforementioned postmodern correlation between film and religion. Against the a/theological point of view, I see film as an essential medium in the postmodern situation of art. Therefore, in the following stage of this essay, I propose to elaborate more closely the postmodern character of film on the basis of its relevant exponents.

\section{The postmodern correlation between film and religion}

In my wanderings through the cultural domain shaped by countless great films, I have pinpointed three roots of the postmodern correlation between film and religion. ${ }^{21}$ In my view, these roots are a kind of focus. Indeed, they indicate points which promote not only a positive, but also a desirable and productive dialogue between film and religion. In their treatment, the notion of postmodern culture receives its proper content. The three foci are the biographical, the apocalyptical and the iconophile.

\subsection{The biographical focus}

With the biographical focus I refer to the postmodern significance of a number of successful and awarded films, namely, The Mission (1986) by Roland Joffé, Romero (1989) by John Duigan and Daens (1992) by Stijn

21 The argument that I develop here emerges from the studies I have published in Dutch. Here I only mention: De horizon van de tragische mens. Een cultuurfilosofisch gesprek met het filmoeuvre van Andrei Tarkovskij (Antwerpen: De Nederlandsche Boekhandel, 1984) and Het licht van de schepping. De religiositeit van de beeldcultuur (Averbode: Altiora, 1992). In these books and also in the Dutch film periodical MediaFilm (Brussel, KFL), I have published studies on most of the films I mention in the following pages. 
Coninx.22 Although they are of different aesthetic quality, the three are valuable films acclaimed by large audiences. These films are highly relevant to the context of religion in postmodern culture. Formulated in cinematographical language, their function can be described as a "flash-back".

In their own authentic ways, each one retrieves, and brings to the fore, an important religious moment of a forgotten past. Their postmodern cultural relevance appears on the big stage of feature films as significant antimodern in two different respects. First, they give a vision of the history of the church that rejects the modernist attempt to portray religion as an outdated issue. Second, they remind modern man that religion cannot be plausibly conceptualized as an unevoquivocal and ideological appearance in history. Especially through films like The Mission and Daens, the contemporary audience is reminded that in some important cases religion played a positive role in the social and cultural struggle of the 18th and 19th century respectively. It was the period in which the Enlightenment with its modernistic ideologies of free-thinking liberalism and socialism scored triumphs and was not afraid of using violence in order to acquire political and economical power and to manipulate the church or destroy its engaged priests. That took place during the 20th century in the communist states, but also, as the film Romero shows, in the nationalistic states where the church only was tolerated when she agreed to be a political servant. The Mission opens a black page in the history book written by modernism in the period of Latin-American Jesuit missions, the so-called Reducciones. Dictated by the modernistic idea of enlightened progress, this period had always been expunged from European memory. ${ }^{23}$ In turn, the film Daens brought about a public rediscovery in Flanders of a forgotten page of the Belgian history book, written during the liberal and anticlerical period of the modern Belgian state.

One distinguishing feature of the mentioned films is that they do not derive their content from any sort of premodern clericalism. In these films the postmodern cultural expression is in no way an alibi for "a return to traditional religion ". ${ }^{4}$ In each, religion finds authentic expression in the biographical postmodern focus. The argument can be made that the three films portray religion far beyond the modernistic vision, wherein it is condemned as an archaic ideological system, and that they instead focus on a biographical religious figure without falling

22 Other films that can be mentioned in this context, are Hiver 54 (Denis Amar, 1989) and To Kill a Priest (Agnieszka Holland, 1988).

23 Roland Joffé, quoted about The Mission in the press file of Excelsior Films (Belgium), says: "The Mission recreates one of the historical moments in which we lost our innocence." (Author's translation)

24 Mark C. Taylor, Disfiguring, 317: „Postmodernism that is not a disguised modernism does not involve a return to traditional religion ..." 
back into a traditionalistic hagiography. The biographical focus reveals a very interesting postmodern way of presenting religion from the standpoint of a concrete man, who has his existential roots in a concrete time and world. In the contemporary postmodern situation, it is precisely the film-image which has the power to signal in a manner accessible and reliable for everyone that religion is not a dried up existential and historical source. ${ }^{25}$ In contrast with the vision of the industrial machine in Soviet films, church architecture in each of the three films appears as an enduring metaphor of religious culture. By making the architectural signs of some historical churches an integral part of a biographical portrait, postmodern religion film can dissociate itself from the typical modernistic vision on churches as empty and deathly archives. 26

\subsection{The apocalyptic focus}

Each of the three films has in a sense an apocalyptic ending. So they introduce a second important focus of the postmodern correlation between film and religion. In the apocalyptic focus of postmodern culture the possibilities of both film and religion are more closely geared to one another. Particularly in the Jewish-Christian religious heritage, the apocalyptic experience is crucial, as was made clear by the historic decision to round off the Christian canon of the Bible with the Book of Revelation. And the fact that the Book of Apocalypse is written in a flamboyant and visionary style full of visual metaphors, makes possible a correlation with postmodern film expression.

Through their sensitivity for the realm of what I call the horizon of time, the biblical Apocalypse and the film medium are structurally related to each other in their apocalyptical sense for the openness of time. That sense is encouraged by the will to see the life of man on the existential dividing line (horizon) between the known and the unknown, the past and present on the one hand, the future on the other. Indeed, through its religious visionary openness, the Apocalypse is able both to

25 In this context, it is meaningful to mention also the film Gandhi (Richard Attenborough, 1982).

26 Some significant films of the last two decades to be mentioned here are, in a chronological order: Le Diable Probablement (Robert Bresson, 1977), Nostalghia (Andrei Tarkovskij 1983), A Prayer for the Dying (Mike Hodges, 1987), Babettes Gaestebud (Gabriel Axel, 1987), Sous le soleil de Satan (Maurice Pialat, 1987), La leggenda del santo bevitore (Ermanno Olmi, 1988), The Navigator: A medieval Odyssey (Vincent Ward, 1988), Jésus de Montréal (Denys Arcand, 1989), We're No Angels (Neil Jordan, 1989), Marcellino, Pane e Vino (Luigi Comencini, 1991), The Miracle (Neil Jordan, 1991), L'Annonce faite a Marie (Alain Cuny, 1991), Bad Lieutenant (Abel Ferrara, 1992), La Belle Histoire (Claude Lelouch, 1992), Sister Act (E. Ardolino, 1992), Sommersby (Jon Amiel, 1993). 
take account of the suffering of man living on earth and to see in it an "Advent" context and, by doing so, to liberate it from the despair of pessimism. The theologian Schillebeeckx rightly describes the biblical apocalyptic texts as "a religious philosophy of life“.27

Film can also develop into such a philosophy of life in a technological society. The postmodern condition thereto is that film frees itself from any kind of modernism, because modernism always cultivates an optimistic vision on human history. Such an attitude weakens the visionary power of the film-image. But in the postmodern culture, film can both discover and explore its affinity with the religious apocalyptic vision, inasmuch as film, with its visual and moving essence, stands firmly anchored in time. This has been very well understood by none other than the Russian director Andrei Tarkovsky, as is attested by his brillant movies and his inspiring film-theoretical book Sculping in Time!

Tarkovsky's film oeuvre opens with the feature film Ivan's Childhood (1962), in which he remembers the apocalyptical World War II, and closes with the film The Sacrifice (1986). In the latter, the apocalyptical sequences of the burning house empowers the visual pregnancy of the whole film. His complete cinematographical work stems from a sharp eye for the continuous suffering of man in history, even in the industrial machine culture (World War II/Ivan's Childhood) and in the super-industrial consumption civilization (The Sacrifice). At the same time, the apocalyptic vision in Tarkovsky's films makes clear that there is an openness to the realm of time, i. e. an openness to a coming renaissance which cannot be brought into images. This openness can be found in the Berlin epilogue of Ivan's Childhood as well as in the sublime The Sacrifice-epilogue with the child as waterbearer for the barren tree.

Tarkovsky's film theory also underlines the unbreakable link between the film-image and living time: "The image is cinematographical if it lives in time and if time lives in it from the first shot ${ }^{\prime 2}{ }^{28}$ For him, the authentic relation between the film-image and the facts of life is "the conditio sine qua non and the real criterion for the plastic construction of a film" ${ }^{\prime 29}$ In this vision, all the implications of the religious relevance of film are completely understood. It is totally opposed to the modernistic will to restrict the life of time in the image because of its intention to discourage, neutralize or root out religion belief from modern society. The films of Tarkovsky constitute a paradigma for the

27 E. Schillebeeckx, Jezus. Het verhaal van een levende (Brugge: Emmaüs, 1975), 101. (Authors translation)

28 A. Tarkovsky, Le Temps Scellé (Paris: Ed. de l'Etoile/Cahiers du Cinéma, 1989), 64. (Translation from the French by the author)

29 Ibid. 67. 
correlation between film and religion in postmodern culture. In his film-making, he rigorously draws the cinematographical conclusions from the postmodern awareness of the all-embracing mystery of living time. Under the direction of Tarkovsky, the realm which exceeds the human ego is given the time to express itself. In the hands of a filmmaker as Tarkovsky, the camera - the paint brush of film - takes the time needed to allow things to speak their own language. It lets the director act as the first spectator of the visual story told by real things themselves. In its postmodern significance, the film becomes the visual medium that arises in a decentering of the organizing subject. The authorship of film lets itself be decentered by the plastic power of the appearing elements.

In a decentric direction like Tarkovsky's, the camera seals the life-value of time. It frees things from the all-to-human objectifying gaze. It extends its seal to moving time, to the reality of duration. The cinematographical seal produces evidence of authenticity and delivers a charter which ratifies the life-value of what appears. At the same time, the Tarkovskian film-image protects the reality of time against every wrongful breaking of its seals. Just as in the biblical vision of the Apocalypse, it does not belong to man, and certainly not to the human, all too human ego-man of modernism, to open the divine seals of time. Only the Lamb of God has the right to break the seals of the Book of Life. Tarkovsky refers explicitely in his film Ivan's Childhood to this religious, apocalyptic openness of time with the image of Dürer's etching, The Four Apocalyptic Horsemen, and also in his film Stalker (1979), with the image of John The Baptist, from the famous Ghentian altarpiece painted by the brothers Van Eyck, and with the literal quotation of a passage $(6,12 \mathrm{~b}-17)$ from the Apocalypse.

What is considered impossible in the vision of Taylor's postmodern a/theology, finds its outstanding expression in the postmodern film world: an intense and powerful presence which is not possessed by a human, all too human grasp. By way of the postmodern film-image, presence in culture can make its appearance and offer a great authenticity to religious experience. An excellent example of cinematographical power in a postmodern sense can be found in the perennial masterpiece, The Seventh Seal (1956), of the director Ingmar Bergman. The title of the film refers to Apocalypse 8,1. That Swedish work stands out as the postwar picture of the medieval crusader Antonius Block, for whom the target of real religious struggle is the absurdity of "Death", one of the four apocalyptic horsemen. Its main character discovers that the religious road runs along the paths of life. These paths are revealed by the film-image. Because of that disclosing nature, film acquires an apocalyptic, religious relevance in postmodern society, endangered from the inside by deathly destruction.

Another basic aspect of the apocalyptic focus directs our attention to the never-ending struggle between good and evil in human history, 
in the heart of every man and even in the earthly elements. In the religious tradition of mankind, especially in the Christian tradition, the experience of that struggle has always been a matter of great interest. In a secular way, this apocalyptic dimension can even be found in the core of modernistic and atheistic ideologies. But in the postmodern cultural situation, marked by the disappearance of a central, firm and unchanging moral code, particularly film employs its visual power to evoke the theme of good and evil. Postmodern film emphasizes that the long history of moral values has not yet reached a happy ending. It portrays postmodern man as one for whom the reality of good and bad is not only an enormous problem, but also an undecipherable mystery.

Tarkovsky's films dredge up this existential mystery. Although embued with a completely different style, the same argument also applies to the more commercially successful American action movies, such as Grand Canyon (1991) by Lawrence Kasdan, Bodyguard (1992) by Mick Jackson and Falling Down (1993) by Joel Shumacher. The postmodern cinematographical eye for the apocalyptical struggle between good and evil accentuates that film and religion are working with the same anthropological raw material. In that work they encounter each other as correlative. Of course, that varies from director to director and from film to film. A close resemblance and a large difference are visible between the postmodern European films of Tarkovsky and the American films of Francis Ford Coppola and David Lynch. Within the described apocalyptic cultural context, the resemblance can be found in the absence of a fixed center, particularly of the father character. The difference refers to the fact that in Tarkovsky's The Sacrifice the father character sacrifices himself because he has witnessed the increasing apocalyptical power of evil, whereas in Coppola's Apocalypse Now (1979) and The Godfather saga (1971, 1974, 1990), as well as in Lynch's Twin Peaks/Fire Walk with Me (1992), the father character represents the good, but brings about apocalyptical evil. In the latter films, the complex interwoveness of good and evil expresses in an exemplary manner the postmodern consciousness. That also implies the presence of a religious raw material in those films. It finds its most significant sign in the modest sorrow of the cinematographical gaze that observes the apocalyptic events and behaviour.

In these films, this distress generates a story that emphasizes narratively the loss of innocence during the apocalyptical events. In The Godfather films, the young and innocent Michael Corleone becomes the dreaded and corrupt godfather who finally causes the ruin of his family. And in Twin Peaks/Fire Walk with Me, an anonymous fortune-teller says to Laura Palmer: "When this kind of fire starts, it's very hard to put it out. The tender wings of innocence burn first and the wind rises and then all goodness is in jeopardy ". In the next sequence, Laura cries while listening to someone who melancholically sings the following significant words: "Why did you go, why did you die away from me while whole the world seems to sing? Was it me? Was it you? Questions 
in a world full of blue. How can a heart that is filled with love, start to cry? When whole the world seems so right, how can it die? Was it me? Was it you? Questions in a world full of blue".

In Lynch's films, that postmodern feeling quickly comes to images of a demonic and nihilistic nature. That counts for some sequences in Twin Peaks/Fire Walk with Me and for his film Wild at Heart in its entirety. In these cases, sensational and shocking images reduce the postmodern religious basic elements. And the postmodern apocalyptical view degenerates all too quickly into the nihilistic pose of someone trying to play a morbid game. Tarkovsky and also Kieslowski follow a completely different cinematographical road. In his Dekalog cycle (1988), Kieslowski offers a very clear example of the mysterious, apocalyptical struggle between good and evil in the everyday life of contemporary man. In Dekalog 1 he portrays a father who, self-assured in his modernistic belief in the scientific power of computers, unintentionally causes the death of his son. In its own cinematographical way, the Dekalog cycle makes visible the incapacity of any kind of moralism to decide the apocalyptic struggle between good and evil. In the same sense, it makes clear that this struggle divulges the great mystery of life and death. Together with postmodern film-making, the spectator can see the religious contemporary image as an indispensable mirror, through which he is intensely connected - "religere" - with the wonderful world of time and space. In the cinematic hall of mirrors, postmodern man learns to experience that world religiously through the sign of light. That experience opens the way to an understanding of the third focus of the postmodern correlation between film and religion.

\subsection{The iconophile focus}

In the detailed theory of the French philosopher Gilles Deleuze, the image-mouvement and the image-temps emerge as the two defined structural elements in the substance of film. ${ }^{30}$ Indeed, film draws its support from the fundamental reality of enduring movement, and is, for that reason, also called "motion picture". In the mirror of films like those of Tarkovsky, the full power of the image-mouvement appears as image-temps.

30 G. Deleuze, Cinéma 1. L'image-mouvement (Paris: Les Ed. de Minuit, 1983). Id, Cinéma 2. L'image-temps (Paris: Les Ed. de Minuit, 1985), 7. Refering to Charles Sanders Peirce (1939-1914) and annotating Matière et mémoire (1896) of Henri Bergson (1859-1941), Deleuze elaborates a taxonomy of the cinematographical images and signs. He describes the philosophical background of his study in Cinema 1 as follows: "La découverte bergsonienne d'une image-mouvement, et plus profondément, d'une imagetemps, garde encore une telle richesse qu'il n'est pas sûr qu'on en ait tiré toutes les conséquences. “ 
In the framework of my enquiry into the postmodern correlation between film and religion, I want to emphasize earthly light as the living source of both the image-mouvement and the image-temps. In my view, earthly light constitutes a main point for the further understanding of the religious dimension of postmodern culture and its cinematographical consciousness. ${ }^{31}$ The postmodern development of the film-image places religiosity in the sign of light. After all, the film-image demonstrates not only the power of light, but also brings light to power. Since their origin, film-images appear fully as "light pictures", as sculptures of earthly light. The religious experience of this life-giving power of light has received everlasting expression in the first chapter of the oldest document of the Jewish-Christian religion, the Book of Genesis. In the biblical myth of creation, light is the sole element which is explicitely named twice, $i$. e. in the passages about the first and the fourth days of the creation. And every time, "God saw it was good". In the tradition of Genesis, the light of creation is a source of religious experience. But created light itself becomes an essential source of creation. It brings the earthly realm of time and space into light. The creative power of light shows the lifework of God himself. "Bringing to light" means "having a good eye" for the metaphysical wonder of being, which is not to be searched for in an abstract, invisible and supernatural world, but in the concrete world of earthly life. In religious faith, as expressed in Genesis, the earthly realm of light is a pre-eminent metaphysical place. Religion assigns man the task of not walking around blindly. On the contrary, he is called to hold his eyes open and to discover the wonder of the created "light images" sculpted by creative light.

Since the 20th century, man disposes of a completely new religious medium, the most light-sensitive machine that ever existed and of which former generations could only dream. The idea that the authentic film has a basically religious essence is confirmed by the leading cameraman Henri Alekan. In his interesting study Des Lumières et des Ombres, he notes that "of all means of expression used by filmmakers, light is the most basic one ".32 In his opinion, the task of the contemporary filmmaker consists in organizing and arranging rhythmically light and shadow, although he is not the possessor of light's power. The director comes to the "living images" by integrating the creative nature of light in his personal point of view. When he lets the creative power of light take part in his images, then his film receives an authentic watermark of religiosity.

31 My point of view is different to that of Deleuze. He considers the montage as "l'acte principal du cinéma" that constitutes "l'image du temps" (Cinéma 2 , 51). For me the basis of "l'image-temps" is rather an ontological than a pure esthetical one.

32 H. Alekan, Des lumières et les ombres (Paris: Sycomore, 1984), 79. (Author's translation) 
Precisely in a postmodern culture, the understanding of the light dimension puts us on the right track of the religious dimension of the film-image. However, it is not obvious that each film automatically has a religious dimension. It can be seen only clearly in the iconophile focus of the postmodern correlation between film and religion, namely, the "worthy light image". I mean by this expression that an authentic image is the fulfilled work of creative light. In this framework, the essential antithesis between modernism and the postmodern culture appears to be an important issue in the contemporary cultural confrontation that has the worthy image as its node.

For that confrontation, the difference between Eisenstein and Tarkovsky, especially the difference between Alexander Nevsky (1938) by Eisenstein and Andrei Roublev (1966) by Tarkovsky, has a paradigmatic meaning: Eisenstein ended an article presenting his film in 1939 with the words: "Patriotism - that's our theme“. With his film-project Eisenstein went along with the ideological need of the Soviet Union at the time, mobilizing the people emotionally in view of the military defence of the régime against the attacking troops of Hitler. For that reason, the historical character Alexander Nevsky and the national feelings of the Russian people were fitted into the ideological figure of Stalins's Communist dictatorship. Tarkovsky's Andrei Roublev stands at quite a distance from Eisenstein's film. Tarkovsky's masterpiece also deals with the medieval period of Russian history, but not in view of promoting any possible militaristic and nationalistic abuse of the film and its subject. He made the religious image - the Trinity icon of Andrei Roublev - the main purpose of his epical and lyrical work. Tarkowski wanted to help the spectator to (re)discover the sublime icon. He succeeded in his enterprise by making his own the observing gaze of the painter-monk. Tarkovsky's main character is in no way a military hero who commands, who battles and who triumphs. The painter-monk is a religious man. He contemplates the divine creation with open eyes, following the paths of the revealing light. Tarkovsky's iconophile engagement with the authentic image also expresses itself in basic stylistic differences with Eisenstein's method. In contrast with Eisenstein, not the ,montage' but the uninterrupted living-image itself is the cornerstone of Tarkowsky's cinematographical construction. The style of the film is determined by the film-image that sets itself free for the creative light of life. The modernistic usage of the film-image relates to the iconographic expression of the film-image as does the darkness of night to daylight. The postmodern iconophile attitude lets the filmimage be itself. It is free to become an authentic image, and sets itself free to experience creative light and its plastic, religious power.

The iconophile attitude provides an adequate outlook on 20th century culture with its large quantity of images. This does not mean that we already presence the advent of the worthy image culture; the first is at most a condition for the second. In our cultural situation, the postmodern way of both championing the worthy film image and 
developing an authentic religious culture can be seen as the same. The key role played by directors related to the Christian heritage in the history of filmmaking up to the present day shows us that the worthy film image in postmodern culture can be a religious act of faith..$^{33}$

One basic aspect of it concerns the continous fight with the audiovisual clichés which attempt to dominate and even terrorize vision in our culture. In his essay on the French painter Cézanne, Introducing to his Paintings (1929), the English author D.H. Lawrence clearly argues that "the cliche is the deadly enemy" of a real image. It originates from the difficult "fight with the cliché" ${ }^{34}$ From this vantage-point, we can understand why the contemporary filmmaker in the postmodern culture, with its predominantly audiovisual images, feels an affinity for the painter. He feels they are kindred spirits. He explores the inspiring history of painting with its many examples of painters fighting with themselves and their surroundings. Their life testifies to the spiritual care for the visionary power of the image, related to the inexhaustible creative power of the divine light of life.

That brings us to another stylistic feature of the religious dimension in postmodern cinematographical consciousness. I define it as the iconophile phenomenon of "the image graft". It consists of the creative integration of worthy pictures from the distant or near past into a film. In this case also, the oeuvre of Tarkovsky is a postmodern example of high quality. He inserts a great number of visual quotations into his films. I refer here only to the icon sequences at the end of Andrei Roublev and to the visual leading part of the unfinished da Vinci picture The Adoration of the Wise in The Sacrifice. Tarkovsky grafts the religious experience of the film-image onto the plastic power of valuable pictures from the past. By doing so, he weakens the argument of the dogmatic progress in arts as laid down in modernism, that can only envisage the art of the past as a museum piece. But Tarkovsky demonstrates that worthy images from the past own not only aesthetic, but also spiritual qualities that can be rediscovered in a postmodern time.

Another iconophile aspect of "the image graft" can be seen in some recent films which focus on the work of a painter. In this context, I do not have in mind films such as Van Gogh (1991) by Louis Malle, but rather films like La Belle Noiseuse (1991) by Jacques Rivette and The Quince Tree Sun (1992) by Victor Erice. In the first, Rivette places the

33 G. Deleuze, Cinéma 2, 222: "Certes, le cinéma dès le début eut un rapport spécial avec la croyance. Il y a une catholicité du cinéma (il y a beaucoup d'auteurs expressément catholiques, même en Amérique, et ceux qui ne le sont pas ont des rapports complexes avec le catholicisme)".

34 D.H. Lawrence, "Introduction to his paintings", in: Selected Essays (Middlesex: Penguin Books, 1950, 1969), 367-346, 337-338. 
work of the French painter Bernard Dufour in the forefront; in the second, Erice follows the Spanish painter Antonio López with his camera. Both films respond entirely to what Pasolini called "cinéma de poësie" ${ }^{\prime \prime}$ In the hands of both directors, the film-image is grafted upon the contemplating work of the painter. In this way, also the spectator experiences a liturgy of the gaze. In Rivette's film, the spectator is opened up for a religious look at the naked human body.

Such a way of looking stands in contrast to the countless films in which the human body is visually levelled down to a sex object. As for the film of Erice, the spectator's gaze directs itself meditatively towards the sublime game of sunlight on the leaves of a quincy tree, and the painter celebrates an iconophile liturgy where the traces of the ancient religious experience of creative light, as written down in the verses of Genesis, once again makes themselves felt. The spiritual eye of the two directors declares its solidarity with the painter who patiently and diffidently searches for a picture which does justice to the concrete mystery of being. Such a picture, in a postmodern sense, is never completed. As one can see in the last sequences of Tarkovsky's Andrei Roublev, the Trinity icon bears signs of destruction. In Rivette's film, La Belle Noiseuse, the most important picture is never exposed, not even before the camera. And in The Quince Tree Sun, the painter is unable to follow and represent the cycle of the fruit. In these three films the film-image emerges from the movement and emotion of the open gaze.

In the perspective of the three aforementioned "movies", we can say that the postmodern religious picture is a process of seeing. In this perspective, I read the conclusion of Tarkowsky, noted in his book Sculpting in Time: "Mankind never created something disinterestedly, unless it was the artistic image. Is it perhaps in this, that we have been created in the image and resemblance of God, namely, capable of creativity?" 36 As a comment on that question, it might be meaningful to argue that in the postmodern time, like in no other, unselfish sacrifice acquires a religious significance in godly seeing. Looking with an open gaze on this creation was the work carried through by the Creator on the Seventh Day. Is it perhaps possible to experience the cinematographical image which shines beyond the audiovisual cliche as the Seventh Day of human culture? During such a cinematographical day, the postmodern spectator ist able to, even if only during the twinkling of an eye, surpass his human, all too human littleness and become a kindred spirit with the divine Spectator.

35 P.P. Pasolini, „Le cinéma de poésie", in: L'expérience hérétique. Langue et cinéma (Paris: Payot, 1976), 135-155.

36 A. Tarkovski, Le Temps Scellé, 223. (Translation from the French by the author) (Englisch edition: Sculpting in Time: Bodley Head, 1986, new American ed. 1987) 
ZUSAMMENFASSUNG: Die religiöse Dimension im cinematographischen Bewußtsein der postmodernen Kultur

Der Text beschäftigt sich mit den religiösen und cinematographischen Auswirkungen der sogenannten ,postmodernen' Kultur, die das aktuelle Bewußtsein der Menschen heute im Unterschied zur klassischen Moderne vor allem durch eine Pluralisierung des Wahrheitsbegriffs und eine dezentralisierte und disfigurierte Weltsicht gekennzeichnet sieht.

Im ersten Schritt entwirft der Autor einen Rückblick auf die Entstehung des Films als ein Element der modernen Industrialisierung und Technisierung seit dem 19. Jahrhundert. Anhand der frühen filmtheoretischen Arbeiten von S. Eisenstein weist er am Beispiel der frühen sowjetischen Filmtheorie nach, wie sehr das neue Medium in den Dienst des offensiven Projekts der frühen Moderne gestellt und als einflußreiches Propagandainstrument für die Ausbreitung von Aufklärung und Sozialismus und für den ideologischen Kampf gegen Unmündigkeit und veraltetes religiöses Bewußtsein genutzt wurde.

Im zweiten Schritt beleuchtet der Autor anhand aktueller Filme drei Brennpunkte, an denen sich die postmoderne Beziehung zwischen Film und Religion in der heutigen Kulturlandschaft verdeutlicht: einen biographischen, einen apokalyptischen und einen ikonophilen Fokus. An diesen Brennpunkten zeigt sich, daß Film und Religion heute vielfältig korrelieren und keineswegs mehr als kulturelle Antipoden fungieren. Anhand von Filmen wie ,Mission", ,Romero' und ,Daens' beschreibt der Autor den biographischen Fokus, den apokalyptischen Film rekonstruiert er vor allem anhand der Arbeiten von A. Tarkowskij und den ikonophilen Aspekt anhand moderner Film(sequenzen) über das künstlerische Schaffen zeitgenössischer Maler wie z. B. ,La Belle Noiseuse' von J. Rivette oder, El Sol del Membrillot von V. Erice.

Auf diesem Hintergrund vertritt der Autor die These, daß der zeitgenössische Film eines der zentralen Medien zum Ausdruck religiöser Bewußtseinslagen ist und ein wichtiges Kulturfeld darstellt, auf dem heute religiös über die Situation des Menschen in der modernen Welt reflektiert wird.

\section{RÉSUMÉ: La dimension religieuse dans la conscience cinématogra- phique de la culture "postmoderne"}

Le texte s'intéresse aux effets religieux et cinématographiques de la culture dite "postmoderne“ qui, aujourd'hui, à la différence de la période moderne classique, voit l'actuelle conscience des hommes marquée surtout par une pluralité en ce qui concerne la notion de vérité et par une vue du monde décentralisée et défigurée.

Premièrement, l'auteur trace une rétrospective de la naissance du film en tant qu'élément de l'industrialisation et de l'évolution technique moderne depuis le 19 ème siècle. A l'aide des premiers travaux de S. Eisenstein sur la theorie du film, il prouve en prenant comme exemple las premières théories soviétiques sur le film, combien le nouveau moyen audiovisuel a été mis au service du projet offensif au début des temps modernes et qu'il a été utilisé en tant $\mathrm{qu}^{\prime}$ instrument puissant de propagande pour la diffusion de l'information et du socialisme ainsi que pour la lutte idéologique contre la minorité et une conscience religieuse vieillie.

Deuxièmement, l'auteur donne des éclaircissements, à l'aide de films récents, sur trois foyers qui expliquent la relation "postmoderne“ entre film et religion dans le paysage culturel actuel. A partir des ces foyers, on voit que film et religion ne font aujourd'hui absolutement plus fonction d'antipodes culturels. A l'aide de films tels que "Mission", "Romero" et "Deans", l'auteur décrit le foyer biographique, il reconstruit le film apocalyptique surtout à l'aide des travaux de A. Tarkowskij et l'aspect iconophile à l'aide (de séquences) de films modernes sur la création artistique de peintres contemporains tels que par exemple "la belle Noiseuse“ de J. Rivette on "El sol del Membrillo“ d. V. Erice. 
En se servant de cette toile de fond, il soutient que le film contemporain est l'un des moyens audiovisuels le plus importants pour l'expression d'états de conscience religieux et qu,il représente un domaine culturel important ou on $s^{\prime}$ 'intéresse, aujourd'hui, d' un point de vue religieux, à la situation de l'homme dans le monde moderne.

RESUMEN: La dimensión religiosa en la consciencia cinematográfica de la cultura postmoderna

El texto se ocupa de los efectos religiosos y cinematográficos de la llamada "cultura postmoderna" que ve caracterizada la consciencia del ser humano de hoy, a diferencia de la modernidad clásica, ante toto por una pluralización del concepto de verdad y de una visión del mundo decentralizada y desfigurada.

En un primer paso el autor esboza una mirada retrospectiva del nacimiento del film como un elemento de la industrialización y tecnificación moderna desde el siglo XIX. Basándose en los primeros trabajos teóricos sobre cinematografía de $\mathcal{S}$. Eisenstein demuestra, teniendo como paradigma, las primeras teorías de la cinematografía soviética, cuánto fue usado el nuevo medio al servicio de un proyecto ofensivo de la primera modernidad y como un valioso instrumento de propaganda para la divulgación de la concepción racional del mundo y del socialismo y para la lucha ideológica contra la dependencia paternalista y la consciencia religiosa retrograda.

En el segundo paso el autor aclara en base a las más actuales películas tres puntos centrales, a través de los que se elucidan las relaciones postmodernas entre film y religión en el espectro cultural actual: un foco biográfico, uno apocalíptico, uno iconófilo. En estos tres puntos se muestra que el film y la religión correlatan en muchos aspectos y de ninguna manera actuan como antípodas culturales. En base a películas como "La misión", "Romero" y "Daens" el autor describe el foco biográfico; reconstruye el film apocalíptico sobre todo a partir de los trabajos de A. Tarkowskij; y el aspecto iconófilo partiendo de secuencias filmicas modernas de la creación artística de pintores contemporáneos, como por ej. „La Belle Noiseuse“ de J. Rivette o „El sol del Membrillo" de V. Erice.

Apoyándose en ésto el autor propone la tesis de que la cinematografía actual es uno de los medios centrales para la expresión de la situación de consciencia y representa un importante campo cultural en el que se reflexiona sobre la situación del ser humano en el mundo moderno. 